\title{
Quantification of myocardial perfusion based on signal intensity of flow sensitized MRI
}

\author{
Sumeda B Abeykoon ${ }^{1,2^{*}}$, Janaka Wansapura ${ }^{2}$ \\ From 15th Annual SCMR Scientific Sessions \\ Orlando, FL, USA. 2-5 February 2012
}

\begin{abstract}
Summary
A new method to quantify myocardial perfusion was developed based on slice select $\left(M_{S}\right)$ and non-select $\left(\mathrm{M}_{\mathrm{G}}\right)$ inversion recovery acquisitions at a single inversion time. A modified Bloch equation was solved to obtain an analytical expression for perfusion $(\mathrm{P})$ in terms of $\Delta \mathrm{M}_{\mathrm{SG}}=\mathrm{M}_{\mathrm{S}}-\mathrm{M}_{\mathrm{G}}$ The average myocardial perfusion of healthy $\mathrm{C} 57 \mathrm{BL} / 6$ mice measured using this technique $(\mathrm{P}=5.7 \pm 0.4 \mathrm{ml} / \mathrm{g} / \mathrm{min})$ agreed with that measured using traditional techniques and it had a high reproducibility with mean standard deviation of $3.6 \%$ between repeated measures. Perfusion maps of ischemia-reperfusion mice showed significantly low perfusion $(\mathrm{P}=1.6 \pm 0.3$ $\mathrm{ml} / \mathrm{g} / \mathrm{min}$ ) in the infarcted regions compared to that of remote regions $(\mathrm{P}=4.1 \pm 0.3 \mathrm{ml} / \mathrm{g} / \mathrm{min}, \mathrm{p}=0.004)$.
\end{abstract}

\section{Background}

The arterial spin labeling technique based on the T1 relaxation time of tissue ( $\mathrm{T} 1$ method) can be used to quantify myocardial perfusion without the use of exogenous contrast materials[1]. However accurate estimation of $\mathrm{T} 1$ relaxation times in the heart, especially in mice is difficult and can require long scan time. As an alternative, we developed a method to quantify myocardial perfusion based on the signal intensity(SI method)of flow sensitized MRI.

\section{Methods}

Myocardial tissue was modeled as intra and extra vascular compartments with fast exchange of spins in between them[1]. The flow sensitization was achieved by slice select $\left(M_{S}\right)$ and non-select $\left(M_{G}\right)$ inversion recovery acquisitions at a single inversion time. A steady state gradient echo image (Msa) was also acquired to normalize receiver characteristics. A modified Bloch equation was solved for this acquisition scheme to obtain an analytical expression for perfusion (P) in terms of $\Delta \mathrm{M}_{\mathrm{SG}}=$ $\mathrm{M}_{\mathrm{S}}-\mathrm{M}_{\mathrm{G}}$ as follows:

$\mathrm{P}=<\Delta \mathrm{M}_{\mathrm{SG}}(\mathrm{t}) \cdot \lambda / \mathrm{M}_{\mathrm{sa}}(\mathrm{t})>/\left(2-\operatorname{Exp}\left(-\mathrm{TR} / \mathrm{T}_{1 \mathrm{c}}\right)-\mathrm{TI} / \mathrm{T}_{1 \mathrm{c}}\right) \cdot \mathrm{T} 1$

where $\mathrm{T}_{1 \mathrm{c}}=$ relaxation time of blood, $\lambda=$ spin density ratio and $\mathrm{T} 1=$ tissue relaxation time. After validating with flow phantoms (data not shown) the SI method was compared with the conventional $\mathrm{T} 1$ method in healthy $\mathrm{C} 57 \mathrm{BL} / 6$ mice $(\mathrm{n}=12)$. A repeated in vivo experiment was carried out to test the reproducibility of the SI method. Finally, quantitative perfusion maps were obtained in a mouse model of ischemia-reperfusion $(n=4)$ in comparison to delayed Gd enhancement. All experiments were performed on a Bruker 7T scanner and gated gradient echo IR-FLASH and IR- Lock Locker sequences were used for SI and T1 methods with $\mathrm{TE}=1.7 \mathrm{~ms}$, FOV $=2.5 \times 2.5 \mathrm{~cm} 2$, matrix size $=128 \times 64$, slice thickness $=2 \mathrm{~mm}$ and TR $($ SI method $) \approx 10 \times \mathrm{RR}, \mathrm{TR}(\mathrm{T} 1$ method) $\approx 40 \times R R$.

\section{Results}

The mean left ventricular perfusion in mice derived from the SI method $(\mathrm{P}=5.7 \pm 0.4 \mathrm{ml} / \mathrm{g} / \mathrm{min})$ agreed with that obtained from the conventional T1 method $(\mathrm{P}=5.6$ $\pm 0.3 \mathrm{ml} / \mathrm{g} / \mathrm{min}$ ) and that quantified with fluorescent microspheres $(\mathrm{P}=5.7 \pm 0.3 \mathrm{ml} / \mathrm{g} / \mathrm{min})[2]$. SI method had a high reproducibility with mean standard deviation of $3.6 \%$ between repeated measures. Perfusion maps of ischemia-reperfusion mice showed (Figure 2) significantly low perfusion $(\mathrm{P}=1.6 \pm 0.3 \mathrm{ml} / \mathrm{g} / \mathrm{min})$ in the hyper intense regions of the corresponding delayed enhanced image compared to remote regions $(\mathrm{P}=4.1 \pm 0.3 \mathrm{ml} / \mathrm{g} /$ min, $\mathrm{p}=0.004)$.

Physics, University of Cincinnati, Cincinnati, OH, USA

Full list of author information is available at the end of the article

(c) 2012 Abeykoon and Wansapura; licensee BioMed Central Ltd. This is an open access article distributed under the terms of the Creative Commons Attribution License (http://creativecommons.org/licenses/by/2.0), which permits unrestricted use, distribution, and reproduction in any medium, provided the original work is properly cited. 


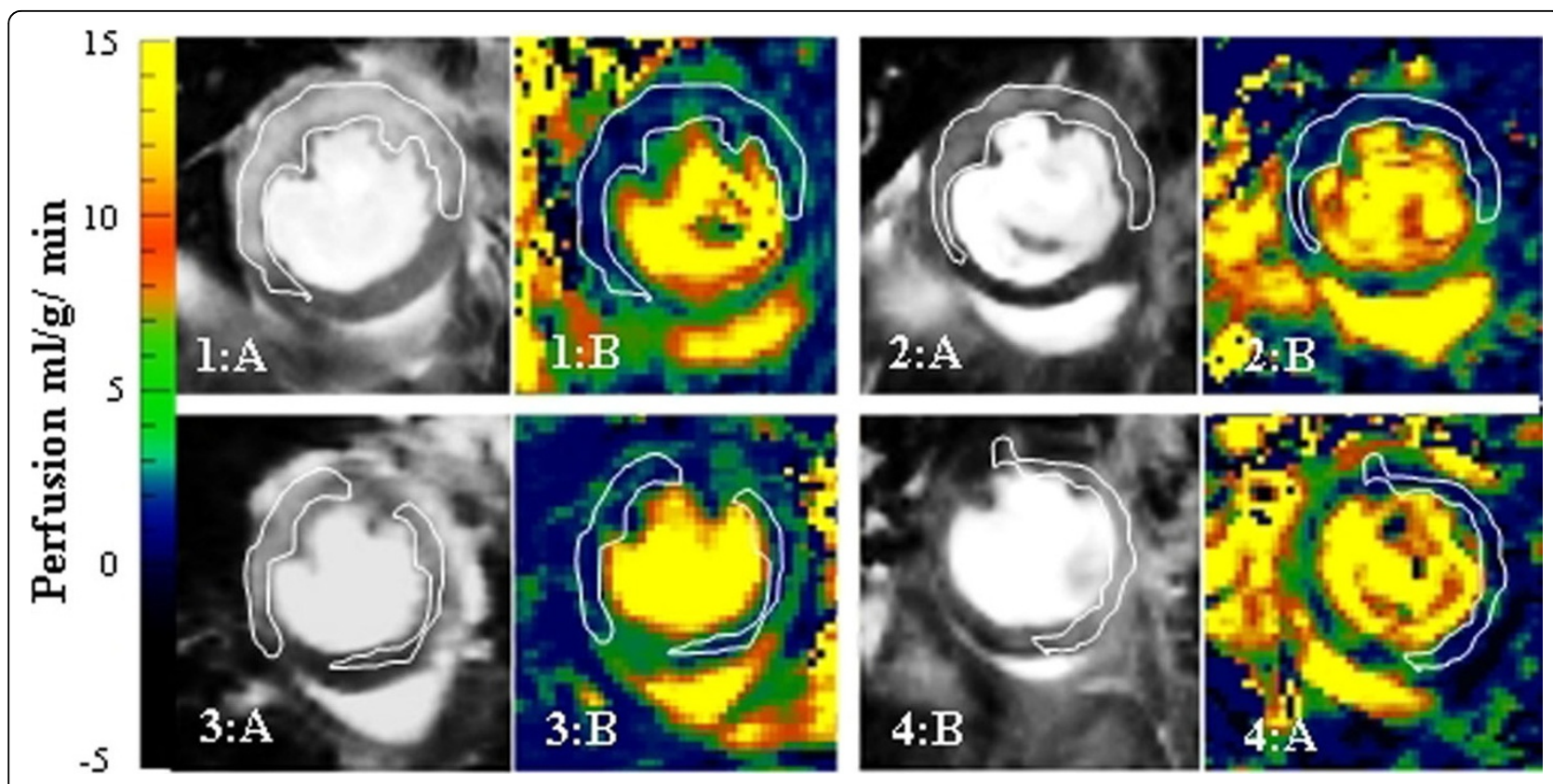

Figure 2 Perfusion deficit regions (right) corresponded well with the myocardial delayed enhancement (left).

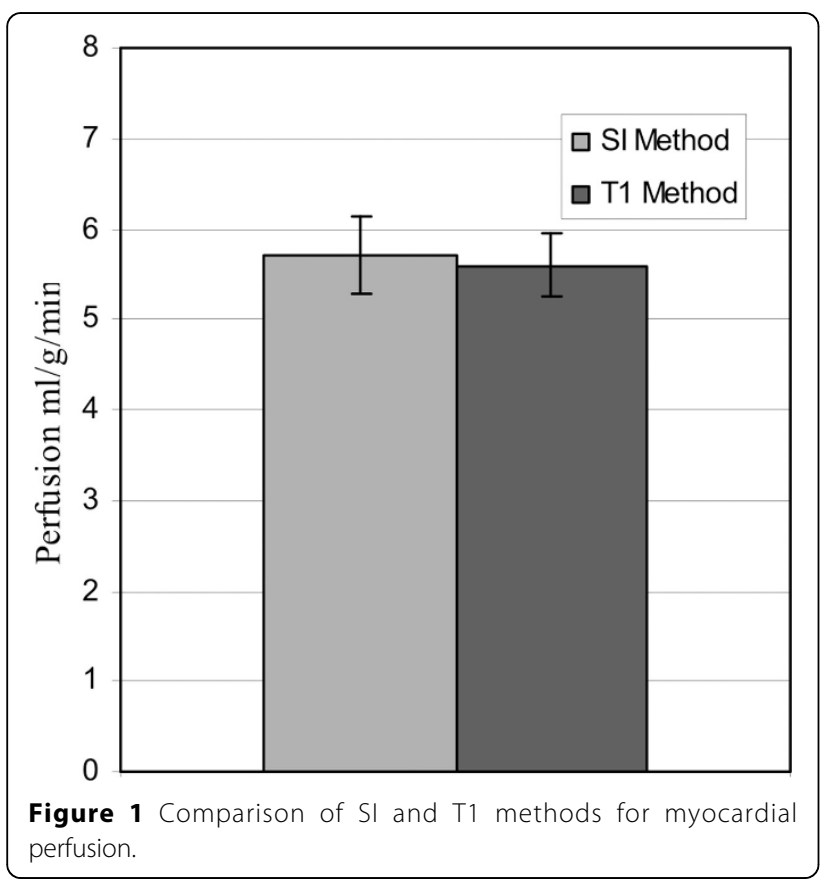

\section{Conclusions}

The SI method for perfusion is a robust alternative to the conventional T1 method. In mice it reduces scan time considerably (30\%-40\%) and is highly reproducible.

\section{Funding}

NIH.

\section{Author details}

'Physics, University of Cincinnati, Cincinnati, OH, USA. ${ }^{2}$ Radiology, Cincinnati Children Hospital Research Center, Cincinnati, OH, USA.

Published: 1 February 2012

\section{References}

1. Belle V, et al: J Magn Reson Imaging. 1998, 8(6):1240.

2. Richer C, et al: J Magn Reson Imaging. 2000, 36(3):396-404.

\section{doi:10.1186/1532-429X-14-S1-048}

Cite this article as: Abeykoon and Wansapura: Quantification of myocardial perfusion based on signal intensity of flow sensitized MRI. Journal of Cardiovascular Magnetic Resonance 2012 14(Suppl 1):O48.
Submit your next manuscript to BioMed Central and take full advantage of:

- Convenient online submission

- Thorough peer review

- No space constraints or color figure charges

- Immediate publication on acceptance

- Inclusion in PubMed, CAS, Scopus and Google Scholar

- Research which is freely available for redistribution 